\title{
Effects of feeding cassava pulp fermented with Acremonium charticola on growth performance, nutrient digestibility and meat quality of broiler chicks
}

\author{
S. Sugiharto", T. Yudiarti, I. Isroli, E. Widiastuti \& F.D. Putra \\ Faculty of Animal and Agricultural Sciences, Diponegoro University, Semarang, Central Java, Indonesia (50275)
}

(Received 5 November 2016; Accepted 13 January 2017; First published online 27 January 2017)

\begin{abstract}
Copyright resides with the authors in terms of the Creative Commons Attribution 4.0 South African License.
See: http://creativecommons.org/licenses/by/4.0/za

Condition of use: The user may copy, distribute, transmit and adapt the work, but must recognize the authors and the South African Journal of Animal Science.
\end{abstract}

\begin{abstract}
Cassava pulp is an energy-rich by-product of the tapioca industry, and is known as a good media for growing filamentous fungi. It may therefore be not only an alternative to maize in poultry diets, but also a carrier for beneficial fungi. This study aimed to investigate the effects of dietary inclusion of the fungus Acremonium charticola (grown in A. charticola-fermented cassava pulp) (AC-FCP), with or without antibiotic growth promoters (AGPs), on growth performance, nutrient digestibility, and meat quality of broiler chicks. A total of 192 broiler chicks were assigned to one of four dietary treatments, including a control diet (maizesoybean-meal-based diet), control diet + AGPs (neomycin) $(0.0003 \%$ of diet), AC-FCP diet (containing $16 \%$ of AC-FCP), and AC-FCP + AGPs. There was a tendency towards lower feed costs per kilogram live bodyweight (BW) gain in AC-FCP and AC-FCP + AGPs than in the control and control + AGPs birds. The birds fed the AC-FCP diet had greater spleen relative weight than the control and AC-FCP + AGPs birds. The birds fed diets containing AC-FCP and AC-FCP + AGPs had heavier ileum and caecum, and tended to have smaller livers than the control and control + AGPs birds. The 2,2-diphenyl-1-picrylhydrazyl (DPPH) percentage inhibition values were lowest and highest in the AC-FCP and control birds, respectively. The breast meat of the control birds had lower crude protein content than that of other experimental groups. In conclusion, dietary inclusion of AC-FCP reduced the feed cost per kilogram live weight gain of broiler chicks. The fungus $A$. charticola (grown in AC-FCP) seems to play an important role in increasing the relative weight of spleen, ileum and caecum, alleviating oxidative stress, and increasing the protein content of breast muscle of broiler chicks.
\end{abstract}

Keywords: Acremonium charticola-fermented cassava pulp, broilers, digestibility, growth, meat characteristics, oxidative stress

\#Corresponding author: sgh_undip@yahoo.co.id

\section{Introduction}

The broiler industry is currently facing fluctuations in feed costs as the result of the rising prices of conventional feedstuffs. This has encouraged poultry nutritionists to search for alternative feed ingredients. Cassava pulp, which is a by-product of the tapioca industry, has recently been used as an energy source in broiler diets to partly replace maize. However, its utilization is limited by its high fibre and low protein contents (Khempaka et al., 2009). To increase the inclusion level of cassava pulp in chicken diets, fermentation by yeast has been applied (Khempaka et al., 2014). In addition to yeast, fungi are microorganisms that are commonly used for fermenting unconventional feedstuffs. In a previous study, the authors showed that fermenting cassava waste pulp with $A$. charticola, a filamentous fungus isolated from Indonesian fermented dried cassava, and urea could decrease the fibre and increase the protein contents of cassava pulp (Sugiharto et al., 2015). Indeed, the inclusion of 16\% AC-FCP in the diets did not impair the physiological and health conditions of broiler chicks (Sugiharto et al., 2016a).

Aside from their health-promoting purpose, AGPs have long been used to improve nutrient digestibility and growth performance of poultry (Dibner \& Richards, 2005). In addition to AGPs, certain feed additives and functional feedstuffs have commonly been included in poultry diets to enhance the growth rate of broiler chicks, including probiotics, antioxidants, and fermented feed (Lokaewmanee et al., 2012; Sugiharto, 2016). Besides being used separately, AGPs and other feed additives may be used simultaneously to improve the weight gain and feed efficiency of animals. A study demonstrated that the inclusion of AGPs in probioticsupplemented diets improved the performance of weaning pigs (Choi et al., 2011). But the use of AGPs in 
poultry diets is no longer permitted in some countries (especially European Union countries) because of controversy about the phenomena of antibiotic resistance in animals and human beings as consumers (Sugiharto, 2016). Hence, the role of feed additives other than AGPs has become more substantial. Earlier data showed that $A$. charticola exhibited probiotic and antioxidant properties (Sugiharto et al., 2015; 2016b), which may be beneficial for chickens. The authors' previous work showed that cassava pulp was a good media for growing the fungus (Sugiharto et al., 2015). This feedstuff, therefore, may not only be an alternative to maize in poultry diets, but also be a carrier for $A$. charticola.

Probiotic administration is associated with improved chemical, nutritional, and sensorial properties of broiler meat (Liu et al., 2012). Likewise, dietary antioxidant is effective in improving the meat quality of broilers, especially under oxidative stress (Salami et al., 2015). If one considers the improving effect of AGPs on the nutritional composition of broiler meat, the administration of AGPs simultaneously with probiotics (and/or antioxidants) may be expected to improve the meat quality of broiler chickens (Abdulla et al., 2017). Irrespective of the use of AC-FCP as a feedstuff (an alternative to maize), the present study aimed to investigate the effects of dietary inclusion of $A$. charticola (grown in AC-FCP) with or without AGPs on growth performance, nutrient digestibility and meat quality of broiler chickens.

\section{Materials and methods}

To prepare the inoculum of $A$. charticola, the fungal stock culture, which was maintained on potato dextrose agar (PDA) (Merck KGaA, Darmstadt, Germany) and stored at $4 \stackrel{\circ}{\circ} \mathrm{C}$, was retrieved, streaked on PDA medium and incubated aerobically at $38 \stackrel{\circ}{ } \mathrm{C}$ for two days. The fungal mycelia were dislodged from the PDA and diluted in $200 \mathrm{~mL}$ sterilized distilled water. The suspension was then used to inoculate $200 \mathrm{~g}$ sterilized dry cassava pulp (87.5\% dry matter) (DM). After aerobic incubation at room temperature for four days, the fungal colony in the inoculation starter was enumerated, based on the colony counting method. The starter was then used to ferment the cassava pulp for an in vivo trial.

Fermented cassava pulp was prepared according to Sugiharto et al. (2015) with certain modifications. Briefly, $10 \mathrm{~kg}$ steamed cassava pulp $(87.5 \% \mathrm{DM})$ was soaked with sterile water $(1: 1)$. The cassava pulp was inoculated with $110 \mathrm{~g} / \mathrm{kg}$ fungal starter (containing fungal colonies $3.6 \times 10^{10} \mathrm{cfu} / \mathrm{g}$ ) and $41 \mathrm{~g} / \mathrm{kg}$ urea and then thoroughly mixed. The mixture was incubated for four days and turned every two days. The AC-FCP was sundried for two days before use in the in vivo experiment. Proximate analysis (AOAC, 1995) showed that AC-FCP contained (as-dry basis) $2,887 \mathrm{kcal} / \mathrm{kg}$ gross energy, $8.5 \%$ crude protein, $1.18 \%$ crude fat, $20.8 \%$ crude fibre, and $2.20 \%$ total ash.

A total of 192 male Lohman MB-202 day-old-chicks that had been purchased from a local hatchery were placed in an open-sided naturally ventilated broiler house. The chicks were raised on a commercial starter diet and randomly allotted to 24 wire-netting floor pens $(1.20 \times 1 \mathrm{~m})$, equipped with round bottom feeders and manual drinkers, at 11 days old. Six pens per treatment were assigned to each of four experimental diets, including the control diet (maize-soybean-meal-based diet), control diet + AGPs (0.0003\% of diet), AC-FCP diet (containing 16\% AC-FCP) and AC-FCP + AGPs. The diets were formulated to be isonitrogenous and isocaloric and met the Indonesian National Standards for Broiler Feed (SNI, 2006) (Table 1). The dietary level of AC-FCP used in the present study was based on Sugiharto et al. (2016a), which reported no detrimental effects of AC-FCP on physiological and health conditions when included up to $16 \%$ in broiler diets. Neomycin was used in this trial, because this antibiotic is commonly used in poultry feed as AGPs in Indonesia. The dose of neomycin in this study was in accordance with that used in commercial practice in Indonesia. The diets were fed ad libitum in mash form until the end of experiment (day 34). The birds were given free access to water throughout the trial. The birds were vaccinated with commercial Newcastle disease virus (NDV) vaccine on day 4 through eyedrops and on day 21 through drinking water. Bodyweight (BW), feed intake and feed conversion ratio (FCR) were recorded at days 21, 28 and 34 . The present study was approved by the Animal Ethics Committee of the Faculty of Animal and Agricultural Sciences, Diponegoro University.

At 28 days old, 24 broiler chicks with relatively uniform weight $(981 \pm 5.94 \mathrm{~g})$ (mean $\pm \mathrm{SD}$ ) were placed in individual cages $(20 \times 35 \times 45 \mathrm{~cm})$. Chromic oxide $\left(\mathrm{Cr}_{2} \mathrm{O}_{3}\right)$ was added $(0.3 \%$ of diet $)$ to the diets as an indigestible marker for measuring total tract digestibility. Excreta were collected for two days, sprayed with $5 \%$ hydrochloric acid, and sundried for two days. Proximate analysis was conducted to determine the DM, organic matter, and total nitrogen in diets and excreta, according to the standard methods (AOAC, 1995).

At day 34 , one bird from each pen was randomly selected, from which blood was obtained from the bird's wing veins (before water and feed were offered) and collected in vacutainers, which did not contain anticoagulant. The blood was allowed to clot for two hours at room temperature. After centrifugation at 2,000 $\mathrm{rpm}$ for $15 \mathrm{~min}$, the serum was obtained and stored at $-20^{\circ} \mathrm{C}$ until serum antibody titer and antioxidant activity were determined. After being weighed, the same birds were slaughtered, de-feathered, and 
Table 1 Ingredients and nutrient composition (as-dry basis) of experimental diets

\begin{tabular}{|c|c|c|c|c|}
\hline \multirow{2}{*}{ Items (\%, unless otherwise noted) } & \multicolumn{4}{|c|}{ Dietary treatments } \\
\hline & Control diet & Control diet + AGPs & AC-FCP & $A C-F C P+A G P s$ \\
\hline Maize & 59.0 & 59.0 & 45.5 & 45.5 \\
\hline Soybean meal & 29.0 & 29.0 & 23.5 & 23.5 \\
\hline AC-FCP & - & - & 16.0 & 16.0 \\
\hline Fish meal & 9.00 & 9.00 & 12.0 & 12.0 \\
\hline Broken rice & 0.75 & 0.75 & 1.23 & 1.23 \\
\hline DL-methionine & 0.23 & 0.23 & 0.23 & 0.23 \\
\hline L-lysine & 0.06 & 0.06 & 0.06 & 0.06 \\
\hline Limestone & 1.01 & 1.01 & 0.53 & 0.53 \\
\hline Dicalcium phosphate & 0.20 & 0.20 & 0.20 & 0.20 \\
\hline Premix $^{1}$ & 0.50 & 0.50 & 0.50 & 0.50 \\
\hline $\mathrm{NaCl}$ & 0.25 & 0.25 & 0.25 & 0.25 \\
\hline Neomycin & - & 0.0003 & - & 0.0003 \\
\hline \multicolumn{5}{|l|}{ Calculated composition: } \\
\hline Metabolizable energy $(\mathrm{kcal} / \mathrm{kg})^{2}$ & 2,896 & 2,896 & 2,877 & 2,877 \\
\hline Crude protein & 22.5 & 22.5 & 22.2 & 22.2 \\
\hline Crude fat & 3.70 & 3.70 & 3.52 & 3.52 \\
\hline Crude fibre & 2.69 & 2.69 & 5.51 & 5.51 \\
\hline Calcium & 1.04 & 1.04 & 1.00 & 1.00 \\
\hline Total phosphorus $^{3}$ & 0.54 & 0.54 & 0.58 & 0.58 \\
\hline Methionine & 0.67 & 0.67 & 0.66 & 0.66 \\
\hline Lysine & 1.46 & 1.46 & 1.42 & 1.42 \\
\hline \multicolumn{5}{|l|}{ Analysed composition: } \\
\hline Metabolizable energy $(\mathrm{kcal} / \mathrm{kg})^{2}$ & 3,216 & 3,264 & 3,220 & 3.237 \\
\hline Dry matter & 86.5 & 87.2 & 82.6 & 83.4 \\
\hline Crude protein & 20.2 & 20.1 & 19.8 & 19.7 \\
\hline Crude fat & 3.71 & 4.21 & 3.92 & 3.87 \\
\hline Crude fibre & 6.83 & 6.21 & 6.59 & 6.81 \\
\hline Ash & 10.1 & 10.0 & 10.5 & 9.74 \\
\hline
\end{tabular}

${ }^{1}$ Mineral-vitamin premix provided (per kg of diet) Ca $2.250 \mathrm{~g}, \mathrm{P} 0.625 \mathrm{~g}$, Fe $3.570 \mathrm{mg}$, Cu $0.640 \mathrm{mg}, \mathrm{Mn} 5.285 \mathrm{mg}, \mathrm{Zn}$ $0.003 \mathrm{mg}$, Co $0.001 \mathrm{mg}$, Se $0.013 \mathrm{mg}$, I $0.016 \mathrm{mg}$, vit A $375 \mathrm{lU}$, vit D 150 IU, vit E $0.080 \mathrm{mg}$

${ }^{2}$ Values were obtained based on the formula according to Bolton (1967), in which metabolizable energy $=40.81\{0.87$ [crude protein +2.25 crude fat + nitrogen-free extract] +2.5$\}$

${ }^{3}$ The available data on phosphorus content in AC-FCP were total phosphorus (not available phosphorus); therefore, the phosphorus contents in other feed ingredients were presented in total phosphorus during calculation

Control: control diet (maize-soybean-meal-based diet); control + AGPs: control diet with AGPs (neomycin) $(0.0003 \%$ of diet); AC-FCP: diet containing 16\% of AC-FCP; AC-FCP + AGPs: diet containing AC-FCP and AGPs; AGPs: antibiotic growth promoters; AC-FCP: cassava waste pulp fermented with $A$. charticola.

Key: AGPs

eviscerated. Immediately, the internal organs, carcass, breast and thigh muscles were weighed. The breast muscles were skinned and deboned to measure $\mathrm{pH}$, drip loss and chemical composition of meat. The trial was terminated at day 34, which was in accordance with the average slaughter age of broiler chicks in Indonesia (5 weeks old).

Serum antibody titers to NDV vaccine were measured using haemagglutination inhibition $(\mathrm{HI})$ (Villegas, 1987). The titers were expressed as geometric mean titer $\left(\log _{2}\right)$. The antioxidant activities in serum were measured by a DPPH free radical scavenging assay (Sohaib et al., 2012). Serum (0.5 mL) was 
dissolved in $3 \mathrm{~mL}$ diluted DPPH solution. The absorbances of the resulting solution and the blank were recorded after $30 \mathrm{~min}$ at room temperature. The conversion of the colour of DPPH was read spectrophotometrically at a $517 \mathrm{~nm}$. Inhibition of free radicals by DPPH in percentage (\%) was calculated using the following equation: $\left.100 \times\left(A_{\text {blank }}-A_{\text {sample }}\right) / A_{\text {blank }}\right)$. Carcass characteristics were measured according to Wang et al. (2015) with few modifications. Around $45 \mathrm{~min}$ after slaughter, the breast muscles were weighed and the $\mathrm{pH}$ was measured. The muscles were then placed in a Whirl-pak bag, stored in a refrigerator $\left(5^{\circ} \mathrm{C}\right)$ and reweighed for the final $\mathrm{pH}$ measurement. The muscle drip loss was determined based on the weight loss and expressed as percentage. The samples of breast muscles were analysed for chemical composition according to the standard methods mentioned above.

The experiment was arranged according to a completely randomized design, and the data were analysed using the general linear model procedure of SAS (SAS Institute, 1985). The quantile-quantile plot (Q-Q plot) was employed to check the normality of the data. Pen was considered the experimental unit, and the results are presented as means and standard errors (SE). Duncan's multiple-range test was used to compare treatment means. A significant level of $P \leq 0.05$ was applied, and tendencies were noted at $P<0.10$.

\section{Results}

The data of growth performance of broiler chicks are presented in Table 2. Broiler chicks in the control and control + AGPs groups had greater $(P<0.01)$ final BW and BW gain than those in AC-FCP + AGPs group. Final BW and BW gain of broiler chicks were not different $(P>0.05)$ among the control, control + AGPs, and AC-FCP groups. Feed conversion ratio was lower $(P<0.05)$ in the control and control + AGPs than in AC-FCP and AC-FCP + AGPs birds. There was a tendency $(P=0.07)$ towards the lower feed cost per kilogram live BW gain in AC-FCP and AC-FCP + AGPs than in control and control + AGPs birds.

Table 2 Effect of dietary inclusion of $A$. charticola-fermented cassava pulp on growth performance of broiler chicks (means and SE)

\begin{tabular}{|c|c|c|c|c|c|c|}
\hline \multirow[b]{2}{*}{ Items } & \multicolumn{4}{|c|}{ Treatments } & \multirow[b]{2}{*}{ SE } & \multirow[b]{2}{*}{$P$ value } \\
\hline & Control & $\begin{array}{l}\text { Control + } \\
\text { AGPs }\end{array}$ & AC-FCP & $\begin{array}{l}\text { AC-FCP + } \\
\text { AGPs }\end{array}$ & & \\
\hline${ }^{I^{\prime} i t i a l ~ B W ~(g / b i r d)}{ }^{\top}$ & 298 & 298 & 291 & 298 & 4.00 & 0.57 \\
\hline Final BW (g/bird) ${ }^{2}$ & $1,423^{\mathrm{a}}$ & $1,426^{a}$ & $1,350^{\mathrm{ab}}$ & $1,301^{b}$ & 25.1 & $<0.01$ \\
\hline BW gain $(\mathrm{g} / \mathrm{bird})^{3}$ & $1,125^{\mathrm{a}}$ & $1,129^{a}$ & $1,059^{\mathrm{ab}}$ & $1,004^{b}$ & 24.9 & $<0.01$ \\
\hline $\mathrm{FCR}^{4}$ & $1.61^{\mathrm{a}}$ & $1.60^{\mathrm{a}}$ & $1.73^{\mathrm{b}}$ & $1.75^{\mathrm{b}}$ & 0.04 & 0.02 \\
\hline Feed cost per kg live BW gain ${ }^{5}$ & 0.893 & 0.890 & 0.830 & 0.840 & 0.020 & 0.07 \\
\hline $\begin{array}{l}\text { a,b Means with different superscri } \\
{ }^{1} \mathrm{BW} \text { determined at day } 11 \text { of the } \\
{ }^{2} \mathrm{BW} \text { determined at day } 34 \text { of the } \\
{ }^{3} \mathrm{BW} \text { gain was calculated as fina } \\
{ }^{4} \mathrm{FCR} \text { was calculated as the feec } \\
{ }^{5} \text { Values are presented in USD } \\
\text { attain a kilogram live weight gair } \\
\text { Control: control diet (maize-soy } \\
\text { diet); AC-FCP: diet containing } \\
\text { growth promoters; AC-FCP: cas } \\
\text { ratio }\end{array}$ & $\begin{array}{l}\text { n each row are } \\
\text { beriment } \\
\text { beriment } \\
\text { l minus initial } \\
\text { ake per unit ga } \\
\text { ency as at the } \\
\text { meal-based } \\
\text { AC-FCP; AC } \\
\text { a waste pulp }\end{array}$ & $\begin{array}{l}\text { W } \\
\text { time of study } \\
\text { tiet); control + } \\
\text {-FCP + AGPs } \\
\text { ermented with }\end{array}$ & $\begin{array}{l}\text { to } 34) \\
\text { and were cal } \\
\text { AGPs: contro } \\
\text { diet containi } \\
\text { A. charticola }\end{array}$ & $\begin{array}{l}\text { ulated by the } \\
\text { diet with AGF } \\
\text { g AC-FCP ar } \\
\text { BW: bodywei }\end{array}$ & $\begin{array}{l}\text { of fee } \\
\text { APs; } \\
\text { Ans. }\end{array}$ & $\begin{array}{l}\text { sumed to } \\
\text { J003\% of } \\
\text { antibiotic } \\
\text { onversion }\end{array}$ \\
\hline
\end{tabular}

The data on digestibility and retention of broilers are presented in Table 3. In general, the digestibilities of DM and organic matter, as well as nitrogen retention, were not different $(P>0.05)$ among the experimental groups.

The data of internal organs of broiler are presented in Table 4. Broilers in the AC-FCP group had greater $(P<0.05)$ spleen weight than those in the control and AC-FCP + AGPs groups. The AC-FCP and ACFCP + AGPs birds had greater $(P<0.05)$ weights of ileum and caecum and tended $(P=0.07)$ to have lower weight of liver than the control and control + AGPs birds.

The data on NDV antibody titer and antioxidant activity of broilers are presented in Table 5 . The DPPH percentage inhibition values of the serum were lowest and highest $(P<0.01)$ in AC-FCP and control birds, respectively. There was no difference $(P>0.05)$ in NDV antibody titer among the experimental groups.

The data on carcass traits of broilers are presented in Table 6 . The relative weight of abdominal fat was lower $(P<0.05)$ in birds receiving AGPs than birds that did not receive AGPs. No differences $(P>0.05)$ 
were observed in eviscerated carcasses, giblets, and commercial cuts (breast, thigh, drumstick, and wing) of broiler chickens.

Table 3 Effect of dietary inclusion of $A$. charticola-fermented cassava pulp on nutrient digestibility in broiler chicks (means and SE)

\begin{tabular}{|c|c|c|c|c|c|c|}
\hline \multirow[b]{2}{*}{ Items } & \multicolumn{4}{|c|}{ Treatments } & \multirow[b]{2}{*}{ SE } & \multirow[b]{2}{*}{$P$ value } \\
\hline & Control & $\begin{array}{l}\text { Control + } \\
\text { AGPs }\end{array}$ & AC-FCP & $\begin{array}{l}\text { AC-FCP + } \\
\text { AGPs }\end{array}$ & & \\
\hline Digestibility (\%) & & & & & & \\
\hline Dry matter & 66.6 & 61.2 & 52.0 & 59.7 & 6.36 & 0.46 \\
\hline Organic matter & 67.9 & 62.4 & 51.9 & 59.9 & 6.32 & 0.39 \\
\hline $\mathrm{N}$ retention (\%) & 76.3 & 73.9 & 70.8 & 74.3 & 4.08 & 0.82 \\
\hline
\end{tabular}

Control: control diet (maize-soybean meal-based diet); control + AGPs: control diet with AGPs (neomycin, $0.0003 \%$ of diet); AC-FCP: diet containing 16\% of AC-FCP; AC-FCP + AGPs: diet containing AC-FCP and AGPs; AGPs: antibiotic growth promoters; AC-FCP: cassava waste pulp fermented with A. charticola; N: nitrogen

Table 4 Effect of dietary inclusion of $A$. charticola-fermented cassava pulp on internal and digestive organs of broiler chicks (means and SE)

\begin{tabular}{|c|c|c|c|c|c|c|}
\hline \multirow[b]{2}{*}{ Items (\% live body weight) } & \multicolumn{4}{|c|}{ Treatments } & \multirow[b]{2}{*}{ SE } & \multirow[b]{2}{*}{$P$ value } \\
\hline & Control & $\begin{array}{l}\text { Control + } \\
\text { AGPs }\end{array}$ & AC-FCP & $\begin{array}{l}\text { AC-FCP + } \\
\text { AGPs }\end{array}$ & & \\
\hline Heart & 0.81 & 0.95 & 0.83 & 0.85 & 0.10 & 0.79 \\
\hline Liver & 3.06 & 3.18 & 2.80 & 2.70 & 0.14 & 0.07 \\
\hline Spleen & $0.09^{\mathrm{a}}$ & $0.11^{\mathrm{ab}}$ & $0.13^{\mathrm{b}}$ & $0.09^{a}$ & 0.01 & 0.02 \\
\hline Thymus & 0.19 & 0.19 & 0.25 & 0.22 & 0.03 & 0.40 \\
\hline Bursa of Fabricius & 0.15 & 0.14 & 0.18 & 0.17 & 0.02 & 0.52 \\
\hline Proventriculus & 0.59 & 0.54 & 0.51 & 0.54 & 0.03 & 0.36 \\
\hline Gizzard & 1.44 & 1.42 & 1.42 & 1.56 & 0.06 & 0.28 \\
\hline Duodenum & 0.43 & 0.49 & 0.55 & 0.53 & 0.04 & 0.16 \\
\hline Jejunum & 0.88 & 0.92 & 1.05 & 1.02 & 0.06 & 0.13 \\
\hline lleum & $0.69^{\mathrm{a}}$ & $0.66^{a}$ & $0.82^{\mathrm{b}}$ & $0.84^{\mathrm{b}}$ & 0.04 & 0.01 \\
\hline Caecum & $0.05^{\mathrm{a}}$ & $0.04^{\mathrm{a}}$ & $0.06^{b}$ & $0.07^{\mathrm{b}}$ & 0.00 & $<0.01$ \\
\hline
\end{tabular}

a,o Means with different superscripts in each row are significantly different

Control: control diet (maize-soybean meal-based diet); Control + AGPs: control diet with AGPs (neomycin, $0.0003 \%$ of diet); AC-FCP: diet containing 16\% of AC-FCP; AC-FCP + AGPs: diet containing AC-FCP and AGPs; AGPs: antibiotic growth promoters; AC-FCP: cassava waste pulp fermented with A. charticola

Table 5 Effect of dietary inclusion of $A$. charticola-fermented cassava pulp on serum antibody titers to Newcastle disease virus vaccine and antioxidant activity of broiler chicks (means and SE)

\begin{tabular}{|c|c|c|c|c|c|c|}
\hline \multirow[b]{2}{*}{ Items } & \multicolumn{4}{|c|}{ Treatments } & \multirow[b]{2}{*}{ SE } & \multirow[b]{2}{*}{$P$ value } \\
\hline & Control & $\begin{array}{l}\text { Control + } \\
\text { AGPs }\end{array}$ & AC-FCP & $\begin{array}{l}\text { AC-FCP + } \\
\text { AGPs }\end{array}$ & & \\
\hline Antibody titer ( $\left.\log _{2} \mathrm{GMT}\right)$ & 3.20 & 3.33 & 4.00 & 3.83 & 0.75 & 0.83 \\
\hline $\begin{array}{l}\text { Antioxidant activity (DPPH, \% } \\
\text { inhibition) }\end{array}$ & $27.3^{\mathrm{a}}$ & $19.4^{\mathrm{b}}$ & $10.1^{\mathrm{c}}$ & $19.1^{\mathrm{b}}$ & 2.38 & $<0.01$ \\
\hline \multicolumn{7}{|c|}{ a,b,c Means with different superscripts in each row are significantly different } \\
\hline \multicolumn{7}{|c|}{$\begin{array}{l}\text { Control: control diet (maize-soybean-meal-based diet); control + AGPs: control diet with AGPs (neomycin, } 0.0003 \% \text { of } \\
\text { diet); AC-FCP: diet containing } 16 \% \text { of AC-FCP; AC-FCP + AGPs: diet containing AC-FCP and AGPs; AGPs: antibiotic } \\
\text { growth promoters; AC-FCP: cassava waste pulp fermented with A. charticola; DPPH: 2,2-diphenyl-1-picrylhydrazyl; } \\
\text { GMT: geometric mean titer }\end{array}$} \\
\hline
\end{tabular}

The data on breast meat characteristics of broiler chickens are presented in Table 7. Breast meat from control birds had lower $(P<0.05)$ crude protein content than meat from other birds. The AC-FCP birds had lower $(P<0.05)$ crude ash content in their breast meat than other experimental groups. There was no difference $(P>0.05)$ in $\mathrm{pH}$ and drip loss of breast meat among the birds. 
Table 6 Effect of dietary inclusion of $A$. charticola-fermented cassava pulp on carcass traits of broiler chicks (means and SE)

\begin{tabular}{|c|c|c|c|c|c|c|}
\hline \multirow[b]{2}{*}{ Items } & \multicolumn{4}{|c|}{ Treatments } & \multirow[b]{2}{*}{ SE } & \multirow[b]{2}{*}{$P$ value } \\
\hline & Control & $\begin{array}{l}\text { Control + } \\
\text { AGPs }\end{array}$ & AC-FCP & $\begin{array}{l}\text { AC-FCP + } \\
\text { AGPs }\end{array}$ & & \\
\hline \multicolumn{7}{|c|}{ \% Live weight } \\
\hline Eviscerated carcass & 66.5 & 64.2 & 66.2 & 66.2 & 1.29 & 0.47 \\
\hline Giblets $^{1}$ & 5.31 & 5.54 & 5.05 & 4.75 & 0.29 & 0.27 \\
\hline \multicolumn{7}{|c|}{$\%$ Eviscerated carcass } \\
\hline Breast & 34.2 & 33.9 & 32.5 & 32.1 & 0.70 & 0.11 \\
\hline Thigh & 16.1 & 16.4 & 15.3 & 15.9 & 0.35 & 0.17 \\
\hline Drumstick & 14.4 & 15.0 & 15.2 & 14.8 & 0.42 & 0.58 \\
\hline Wing & 11.9 & 12.7 & 13.0 & 13.0 & 0.39 & 0.20 \\
\hline Abdominal fat & $1.88^{\mathrm{ab}}$ & $1.12^{\mathrm{C}}$ & $2.15^{\mathrm{a}}$ & $1.40^{\mathrm{bc}}$ & 0.22 & 0.02 \\
\hline
\end{tabular}

Table 7 Effect of dietary inclusion of $A$. charticola-fermented cassava pulp on breast meat traits of broiler chicks (means and SE)

\begin{tabular}{|c|c|c|c|c|c|c|}
\hline \multirow[b]{2}{*}{ Items } & \multicolumn{4}{|c|}{ Treatments } & \multirow[b]{2}{*}{ SE } & \multirow[b]{2}{*}{$P$ value } \\
\hline & Control & $\begin{array}{l}\text { Control + } \\
\text { AGPs }\end{array}$ & AC-FCP & $\begin{array}{l}\text { AC-FCP + } \\
\text { AGPS }\end{array}$ & & \\
\hline $\mathrm{pH}_{45 \min }$ & 5.83 & 5.67 & 5.67 & 5.67 & 0.11 & 0.61 \\
\hline $\mathrm{pH}_{24 \mathrm{~h}}$ & 5.52 & 5.48 & 5.53 & 5.55 & 0.03 & 0.36 \\
\hline Drip loss (\%) & 1.59 & 1.89 & 0.71 & 0.74 & 0.50 & 0.26 \\
\hline Moisture (\%) & 74.1 & 74.1 & 74.3 & 73.9 & 0.18 & 0.58 \\
\hline Crude protein (\%) & $22.6^{a}$ & $23.1^{\mathrm{b}}$ & $23.6^{\mathrm{b}}$ & $23.3^{\mathrm{b}}$ & 0.18 & 0.01 \\
\hline Crude fat (\%) & 0.76 & 0.79 & 0.72 & 0.81 & 0.03 & 0.22 \\
\hline Ash (\%) & $0.79^{\mathrm{a}}$ & $0.73^{a}$ & $0.64^{\mathrm{b}}$ & $0.76^{a}$ & 0.03 & $<0.01$ \\
\hline
\end{tabular}

${ }^{\mathrm{a}, \mathrm{b}}$ Means with different superscripts in each row are significantly different

Control: control diet (maize-soybean meal-based diet); control + AGPs: control diet with AGPs (neomycin, $0.0003 \%$ of diet); AC-FCP: diet containing 16\% of AC-FCP; AC-FCP + AGPs: diet containing AC-FCP and AGPs; AGPs: antibiotic growth promoters; $\mathrm{AC}-\mathrm{FCP}$ : cassava waste pulp fermented with $A$. charticola

\section{Discussion}

In the present study, $A$. charticola was used to ferment cassava pulp, not only to improve the nutritional quality of cassava pulp, but also to take advantage of the functional properties (probiotic and antioxidant) of the fungus on broiler performances. The current data showed that broiler chicks that received AC-FCP gained less weight than those that received the control diet or the control diet with AGPs, though the difference was not significant. Indeed, diets containing AC-FCP tended to reduce the feed cost per kilogram live weight gain of broiler chicks. In an earlier work, Khempaka et al. (2014) reported that inclusion of Aspergillus oryzae-fermented cassava pulp up to $16 \%$ of diets did not significantly affect the digestibilities of DM and organic matter or nitrogen retention in broiler chicks. Accordingly, the present data showed no significant effect of dietary AC-FCP and/or AGPs inclusion on the digestibilities of DM and organic matter and nitrogen retention in broiler chicks. This finding may suggest that AC-FCP could be included in broiler rations up to $16 \%$ to partially replace the maize. However, caution should be taken as dietary inclusion of $16 \%$ of AC-FCP resulted in higher FCR values in the present study.

In the present study, there was a tendency toward a lower relative weight of the liver in AC-FCP and AC-FCP + AGPs than in the control and control + AGPs birds. The rationale for this condition was not fully known. However, probiotic activity of $A$. charticola grown in AC-FCP seemed to decrease the weight of liver. Mehr et al. (2007) and Bozkurt et al. (2009) reported a decreased relative liver weight in broilers after feeding probiotic Protexin and probiotic mixture Primalac ${ }^{\circledR}$, respectively. In such cases, probiotics may decrease the population of pathogenic microorganisms in the intestine. As a consequence, less toxin will be produced and liver will have less work in detoxifying these toxin (Mehr et al., 2007). In terms of the antioxidant property of 
the fungus, it might have a minimal effect on the liver weight, as Jang et al. (2014) reported no effect of antioxidants (vitamins $C$ and $E$ ) on the relative weight of liver in broiler chicks. Eventually, the lower liver weight in the present study may confirm that the toxicological effect of urea used as a nitrogen source in the fermentation process did not appear in broiler chicks (Khempaka et al., 2014; Sugiharto et al., 2016a). Birds in AC-FCP group had greater weight of spleen than birds in other experimental groups. The probiotic activity of the fungus grown in AC-FCP seems to play an important role in enhancing the weight of spleen in the present study. In agreement, Awad et al. (2009) showed a greater spleen in the probiotic-supplemented birds than in control. Antioxidant properties of the fungus might also affect the weight of spleen in broiler chicks fed AC-FCP diet. This was supported by Hosseini-Vashan et al. (2016), who found an increased weight of bursa of Fabricius and spleen in broiler chicks fed tomato pomace (as source of natural antioxidants). In this study, the relative weights of ileum and caecum were higher in AC-FCP and AC-FCP + AGPs compared with the control and control + AGPs birds. In such conditions, both probiotic and antioxidant activities of the fungus grown in AC-FCP diets seem to be responsible. This inference was supported because the administration of probiotic Lactobacillus spp. (Olnood et al., 2015) or processed apple peel waste (as a natural antioxidant) (Heidarisafar et al., 2016) increased the small intestinal weight (jejunum and ileum) of broiler chicks.

Rapid growth in broiler chickens has been attributed to a high metabolic rate and thus high production of free radicals (pro-oxidants). Naturally, the bodies of broiler chicks produce antioxidants to prevent the oxidative damage induced by free radicals. Compared with other experimental groups, birds that received an AC-FCP diet exhibited lower antioxidant activity in the serum, as indicated by the lower value of DPPH percentage inhibition. Sohail et al. (2011) suggested that antioxidant production was augmented following the increase of free radical production in broiler chicks. Taken together, the antioxidant capacity of $A$. charticola grown in AC-FCP diets (Sugiharto et al., 2015; 2016b) was perhaps capable of alleviating oxidative stress in broiler chicks and thus the increased production of antioxidants as a natural protective response to oxidative stress did not appear in AC-FCP birds. This inference was supported by Sugiharto et al. (2016c), who reported that feeding gathot (fermented dried cassava from which $A$. charticola was isolated) reduced the heterophil to lymphocyte $(\mathrm{H} / \mathrm{L})$ ratio (indicator of oxidative stress) in broiler chicks compared with the control birds. Owing to the limited number of repetitions, however, the interpretation of the current findings should be taken with caution.

The current data showed that birds that received AGPs had lower abdominal fat than the AGPs-fed birds. This result was in line with Mokhtari et al. (2010), who reported decreased abdominal fat weight in broiler chicks fed avilamycin as an AGP. In this study, feeding AC-FCP did not significantly affect the abdominal fat content of chicks compared with the control. This finding was different from those of Adeyemi et al. (2008), who reported a decrease in abdominal fat content in broiler fed $25 \%$ cassava root meal fermented with rumen filtrate. In contrast, Zhang et al. (2016) reported that dietary inclusion of fermented feed at a level of $6 \%$ significantly increased the abdominal fat percentage of 56 -day-old broiler chickens. The nature and level of inclusion of fermented feed and the conditions of study may explain these contradictory results.

Although the number of repetitions was limited, inclusion of AC-FCP and/or AGPs in the diets increased the protein content of broiler meat in the present study. Concomitant results were reported by Hossain et al. (2012) and Nie et al. (2015), in which dietary supplementation with fermented Alisma canaliculatum and Candida tropicalis-fermented cotton seed, respectively, increased the crude protein content of breast meat of broiler chicks. The mechanism by which AC-FCP increased the protein content of breast meat is unclear, but the enhancing effect of probiotic fungus grown in AC-FCP on the protein efficiency ratio and thus production of protein in the musculature of broilers may be the reason (Khaksefidi \& Rahimi, 2005; Hossain et al., 2012). In terms of the effect of antioxidants on the crude protein content of breast meat, the data in the literature are inconclusive. Rahman \& Kim (2016) reported that dietary supplementation of Nigella sativa seed (source of antioxidant) increased the protein content of broiler meat, whereas Marzoni et al. (2014) showed no effect of dietary natural antioxidants (dry extracts of tomato skin, orange peel, and green tea leaves) on the crude protein content of breast and thigh meat of broiler chickens and Muscovy ducks. With regard to the effect of AGPs on crude protein content of meat, the present findings were different from those reported by other workers, which showed no effect of various AGPs, for example 0.05\% chlortetracycline and HCL + cyanocobalamin (Yang et al., 2003), $0.5 \mathrm{~g} / \mathrm{kg}$ flavomycin (Attia et al., 2011), $0.005 \%$ oxytetracycline (Hossain et al., 2012), and $100 \mathrm{ppm}$ combination of oxytetracycline and neomycin (Abdulla et al., 2017). The rationale for this condition is not fully known, but the various types and doses of AGPs and the conditions of the study may partly explain the conflicting results.

In the current study, crude ash was lower in the meat of AC-FCP birds than in the other experimental groups. This may indicate that meat from AC-FCP broiler chicks had lower retention of minerals. The present finding was different from that of Nie et al. (2015), who showed no effect of fermented cottonseed meal on crude ash of breast muscle of broiler chicks. Several studies have reported enhancing effects (Khaksefidi \& 
Rahimi, 2005) and absent effects (Abdulla et al., 2017) of probiotics on the crude ash content of broiler meat. With regard to the effect of antioxidants on the ash content of broiler meat, Kim et al. (2015) demonstrated that dietary supplementation with $1 \%$ sea urchin shell powder (rich in antioxidants) significantly reduced the ash content of broiler meat, whereas Marzoni et al. (2014) and Rahman \& Kim (2016) reported no effect of dietary natural antioxidant on ash content of meat from broiler chicks. The explanation for the lower ash content in the meat of AC-FCP broiler chicks in the current study therefore remains unelucidated.

\section{Conclusion}

Dietary inclusion of AC-FCP reduced the feed cost per kilogram live weight gain of broiler chicks. The fungus $A$. charticola (grown in AC-FCP) seems to play an important role in increasing the relative weight of spleen, ileum and caecum, alleviating oxidative stress, and increasing protein content of breast muscle of broiler chicks. Further studies with more number of repetitions and longer trial periods are needed to verify the present findings.

\section{Acknowledgements}

The study was fully funded by Diponegoro University through Non-Tax State Revenue (PNBP) No: SP DIPA 042.01.2.400898/2016, 7 December 2015.

\section{Authors' Contributions}

SS designed the study, carried out the animal experiment, data analysis and manuscript writing. II and EW carried out the animal experiment. TY and FDP conducted the laboratory analysis.

\section{Conflict of Interest Declaration}

The authors declare that they have no competing interests.

\section{References}

Abdulla, N.R., Zamri, A.N.M., Sabow, A.B., Kareem, K.Y., Nurhazirah, S., Ling, F.H., Sazili A.Q. \& Loh, T.C., 2017. Physico-chemical properties of breast muscle in broiler chickens fed probiotics, antibiotics or antibiotic-probiotic mix. J. Appl. Anim. Res. 45, 64-70.

Adeyemi, O.A., Eruvbetine, D., Oguntona, T., Dipeolu, M. \& Agunbiade, J.A., 2008. Feeding broiler chicken with diets containing whole cassava root meal fermented with rumen filtrate. Arch. Zootec. 57, 247-258.

AOAC, 1995. Official methods of analysis of the association of analytical chemists, Washington DC, USA.

Attia, Y.A., Zeweil, H.S., Alsaffar, A.A. \& El-Shafy, A.S., 2011. Effect of non-antibiotic feed additives as an alternative to flavomycin on productivity, meat quality and blood parameters in broilers. Arch. Geflügelk. 75, 40-48.

Awad, W.A., Ghareeb, K., Abdel-Raheem, S. \& Böhm, J., 2009. Effects of dietary inclusion of probiotic and synbiotic on growth performance, organ weights, and intestinal histomorphology of broiler chickens. Poult. Sci. 88, 49-55.

Bolton, W., 1967. Poultry nutrition. MAFF Bulletin No.174, HMSO, London.

Bozkurt, M., Küçükyılmaz, K., Çatlıand, A.U. \& Çınar, M., 2009. The effect of single or combined dietary supplementation of prebiotics, organic acid and probiotics on performance and slaughter characteristics of broilers. South Afr. J. Anim. Sci. 39, 197-205.

Choi, J.Y., Kim, J.S., Ingale, S.L., Kim, K.H., Shinde, P.L., Kwon, I.K. \& Chae, B.J., 2011. Effect of potential multimicrobe probiotic product processed by high drying temperature and antibiotic on performance of weanling pigs. J. Anim. Sci. 89, 1795-1804.

Dibner, J.J. \& Richards, J.D., 2005. Antibiotic growth promoters in agriculture: history and mode of action. Poult. Sci. 84, 634-643.

Heidarisafar, Z., Sadeghi, G., Karimi, A. \& Azizi, O., 2016. Apple peel waste as a natural antioxidant for heat-stressed broiler chickens. Trop. Anim. Health Prod. 48, 831-835.

Hossain, M.E., Ko, S.Y., Kim, G.M., Firman, J.D. \& Yang, C.J., 2012. Evaluation of probiotic strains for development of fermented Alisma canaliculatum and their effects on broiler chickens. Poult. Sci. 91, 3121-3131.

Hosseini-Vashan, S.J., Golian, A. \& Yaghobfar, A., 2016. Growth, immune, antioxidant, and bone responses of heat stress-exposed broilers fed diets supplemented with tomato pomace. Int. J. Biometeorol. 60, 1183-1192.

Jang, I.-S., Ko, Y.-H., Moon, Y.-S. \& Sohn, S.-H., 2014. Effects of vitamin C or E on the pro-inflammatory cytokines, heat shock protein 70 and antioxidant status in broiler chicks under summer conditions. Asian-Aust. J. Anim. Sci. 5, 749-756.

Khaksefidi, A. \& Rahimi, Sh., 2005. Effect of probiotic inclusion in the diet of broiler chickens on performance, feed efficiency and carcass quality. Asian-Aust. J. Anim. Sci. 18, 1153-1156.

Khempaka, S., Molee, W. \& Guillaume, M., 2009. Dried cassava pulp as an alternative feedstuff for broilers: Effect on growth performance, carcass traits, digestive organs, and nutrient digestibility. J. Appl. Poult. Res. 18, 487-493.

Khempaka, S., Thongkratok, R., Okrathok, S. \& Molee, W., 2014. An evaluation of cassava pulp feedstuff fermented with A. oryzae, on growth performance, nutrient digestibility and carcass quality of broilers. J. Poult. Sci. 51, 71-79.

Kim, S.C., Chung, Y.H., Chung, T.H. \& Choi, I.H., 2015. Comparative effects of dietary sea urchin shell powder and feed additives on meat quality and fatty acid profiles of broiler breast meat. Acta Sci. Anim. Sci. 37, 289-294.

Liu, X., Yan, H., Lv, L., Xu, Q., Yin, C., Zhang, K., Wang, P. \& Hu, J., 2012. Growth performance and meat quality of broiler chickens supplemented with Bacillus licheniformis in drinking water. Asian-Aust. J. Anim. Sci. 25, 682-689. 
Lokaewmanee, K., Yamauchi, K. \& Thongwittaya, N., 2012. Effects of fermented plant product on growth performance, some blood variables, carcase characteristics, and intestinal histology in broilers. Br. Poult. Sci. 53, 215-223.

Marzoni, M., Chiarini, R., Castillo, A., Romboli, I., De Marco, M. \& Schiavone, A., 2014. Effects of dietary natural antioxidant supplementation on broiler chicken and Muscovy duck meat quality. Anim. Sci. Pap. Rep. 32, 359368.

Mehr, M.A., Shargh, M.S., Dastar, B., Hassani, S. \& Akbari, M.R., 2007. Effect of different levels of protein and Protexin on broiler performance. Int. J. Poult. Sci. 6, 573-577.

Mokhtari, R., Yazdani, A.R., Rezaei, M. \& Ghorbani, B., 2010. The effect of different growth promoters on performance and carcass characteristics of broiler chickens. J. Anim. Vet. Adv. 9, 2633-2639.

Nie, C., Zhang, W., Ge, W., Wang, Y., Liu, Y. \& Liu, J., 2015. Effects of fermented cottonseed meal on the growth performance, apparent digestibility, carcass traits, and meat composition in yellow-feathered broilers. Turk. J. Vet. Anim. Sci. 39, 350-356.

Olnood, C.G., Beski, S.S.M., Choct, M. \& lji, P.A., 2015. Novel probiotics: Their effects on growth performance, gut development, microbial community and activity of broiler chickens. Anim. Nutr. 1, 184-191.

Rahman, M.Md. \& Kim, S.-J., 2015. Effects of dietary Nigella sativa seed supplementation on broiler productive performance, oxidative status and qualitative characteristics of thighs meat. Italian J. Anim. Sci. 15, 241-247.

Salami, S.A., Majoka, M.A., Saha, S., Garber, A. \& Gabarrou, J.-F., 2015. Efficacy of dietary antioxidants on broiler oxidative stress, performance and meat quality: science and market. Avian Biol. Res. 8, 65-78.

SAS Institute, Inc., 1985. SAS user's guide: Statistics, version 5 edition. Cary, NC, USA.

SNI (Indonesian National Standard), 2006. Standard for broiler feed (SNI 01-3930-2006). National Standardization Agency of Indonesia, Jakarta, Indonesia (article in Bahasa).

Sohaib, M., Anjum, F.M., Khan, M.I., Arshad, M.S. \& Shahid, M., 2012. Enhancement of lipid stability of broiler breast meat and meat products fed on alpha lipoic acid and alpha tocopherol acetate supplemented feed. Lipids Health Dis. 11, 1-10.

Sohail, U., Rahman, Z.U., ljaz, A., Yousaf, M.S., Ashraf, K., Yaqub, T. \& Zaneb, H., 2011. Single or combined effects of mannan-oligosaccharides and probiotic supplements on the total oxidants, total antioxidants, enzymatic antioxidants, liver enzymes, and serum trace minerals in cyclic heat-stressed broilers. Poult. Sci. 90, 2573-2577.

Sugiharto, S., Yudiarti, T. \& Isroli, I., 2015. Functional properties of filamentous fungi isolated from the Indonesian fermented dried cassava, with particular application on poultry. Mycobiology 43, 415-422.

Sugiharto, S., 2016. Role of nutraceuticals in gut health and growth performance of poultry. J. Saudi Soc. Agric. Sci. 15, 99-111.

Sugiharto, S., Yudiarti, T. \& Isroli, I., 2016a. Haematological and biochemical parameters of broilers fed cassava pulp fermented with filamentous fungi isolated from the Indonesian fermented dried cassava. Livest. Res. Rural Dev. 28 (retrieved from http://www.Irrd.org//rrd28/4/sugi28053.htm).

Sugiharto, S., Yudiarti, T. \& Isroli, I., 2016b. Assay of antioxidant potential of two filamentous fungi isolated from the Indonesian fermented dried cassava. Antioxidants 5, 1-6.

Sugiharto, S., Yudiarti, T. \& Isroli, I., 2016c. Performances and haematological profile of broilers fed fermented dried cassava (Manihot esculenta Crantz). Trop. Anim. Health Prod. 48, 1337-1341.

Villegas, P., 1987. Avian virus diseases laboratory manual. College of Veterinary Medicine. University of Georgia, Athens, Georgia, USA.

Wang, D., Huang, H., Zhou, L., Li, W., Zhou, H., Hou, G., Liu, J. \& Hu, L., 2015. Effects of dietary supplementation with turmeric rhizome extract on growth performance, carcass characteristics, antioxidant capability, and meat quality of Wenchang broiler chickens. Italian J. Anim. Sci. 14, 344-349.

Yang, C.J., Yang, I.Y., Oh, D.H., Bae, I.H., Cho, S.G., Kong, I.G., Uuganbayar, D., Nou, I.S. \& Choi, K.S., 2003. Effect of green tea by-product on performance and body composition in broiler chicks. Asian-Aust. J. Anim. Sci. 16, 867872.

Zhang, J., Zhu, J., Sun, J., Li, Y., Wang, P., Jiang, R. \& Rahman, Md. R.T., 2016. Effect of fermented feed on intestinal morphology, immune status, carcass and growth performance of Emei Black chickens. FASEB J. 30, 1-1. 